Then in successive chapters we meet Bishop Wilberforce, the leader of the high church faction of the Anglican establishment, Thomas Henry Huxley, by the time of the Origin a man who was already making himself a force in Victorian science and education and a strong opponent of Owen, and Joseph Hooker, the botanist and great friend of Darwin and enthusiastic supporter of evolution through selection. The author writes clearly and people new to the field will find that the pocket pictures are helpful and nicely drawn.

We move on to the details of the debate itself, followed by an analysis showing that a lot of exaggeration was to come in later years as the various participants played up their own roles and successes, sometimes at the expense of total veracity. This is not new territory, because already others (who, to be fair, are referenced) have shown that the encounter was certainly not as one-sided as the evolutionists loved to tell in later years - a distortion which certainly had long legs because, when I did Victorian history at school back in the 1950s, I was treated to a wonderful account of professors slaying bishops in the name of reason and evidence.

Finally, there is a brief reference to the ongoing debates about science and religion, especially as we find today in the attacks being made on Christian belief by the so-called "new atheists." My own feeling is that it is a pity that these two or three pages had not been expanded and made the raison d'etre of the book. It could have been really interesting and informative to compare the clashes back in the 1860s with the clashes today. Are we just seeing in Richard Dawkins a replay of Thomas Henry Huxley, or is there something new going on now? I guess the author just didn't want to put history to this kind of use. Historians of science are terrified of making mention of the present, fearing that they will be accused of the dreadful sin of "Whiggishness," that is of writing history in order to put a gloss on the present. I am not sure that looking at the present through the lens of the past is in fact always trying to privilege the present. Whether it is or not, I am still left with my initial question. Since there is nothing new, why bother to write the book?

Michael Ruse

Florida State University

\title{
Robert Service, Trotsky: A Biography (Cambridge, Mass.: Harvard University Press, 2009).
}

This biography of Trotsky by a Professor of Russian History at Oxford University joins his other publications on Communism. Illustrated with maps and photographs, Trotsky: A Biography draws from an autobiography, letters, party and military correspondence, confidential speeches, and medical records. This book is a substantial contribution to an intriguing historical figure committed to 
collective farming, ousted by Stalin, and assassinated by Soviet intelligence agents in 1940.

The account is intended to "dig up the buried life" (4) of Trotsky in labourious detail. Service's critical approach examines his exceptional qualities as an orator and administrator and investigates his personal self-absorption. Service does not foster Stalin's depiction of Trotsky as a traitor to the October Revolution and provides comprehensive coverage of his overthrow of the Provisional Government in October 1917, deportation in 1929, and political asylum in Turkey, France, Norway and Mexico.

The autobiography forms the basis of the early years from 1879 to 1913. Faced with Jewish discrimination, Leiba Bronstein adopted the pseudonym Trotsky at twenty-three. The fifth of eight children, he was an intelligent and active son of a well-established peasant family in Kherson province who had moved to a nearby town for Christian schooling. His Marxist politicization began at the age of sixteen and led to his imprisonment in Nokolaev and Moscow. In 1902, he abandoned his first wife Alexandra and his two children after serving a prison term in Siberia.

Meanwhile, the Social-Democratic Workers' Party established itself at the Second Party Congress and the battle heightened between the Mensheviks and Bolsheviks. During exile in London and Paris, Trotsky emerged as a spokesperson for Marxism within the party and met and married his second wife Natalya. He faced a trial and fifteen months gaol after challenging the revolution in St. Petersburg. The author offers a cautious view of his role in the October Revolution of 1904-05 by stating that in "a faction-ridden Marxist movement his openness to all sides in every dispute made him many enemies" (113).

Trotsky persisted in his struggle for a working-class revolution serving labour. Hostile to Plekhanov and Lenin, his Bolshevism began annoying the rest of the party. He joined other anti-war socialists during the First World War, was deported from France, stayed in New York, and was briefly detained in Amherst, Nova Scotia before intervention for his return to Moscow. Thirty-eight years of age in 1917, he faced temporary arrest before his attempt to take over the Petrograd Soviet. Allied with Lenin, his overthrow of the Provisional Government in October directly challenged the Mensheviks and SocialistRevolutionaries.

The 1920s were instrumental to the decline of Lenin and Trotsky and to the ascendancy of Stalin. Trotsky was faithful to the Bolsheviks and to the Red Army during the Civil War. His efforts concentrated on the Third International and spreading revolution in Europe. The factional rivalry between Stalin and Trotsky came to a head in 1926 when Stalin promoted administrators loyal to him to the upper party echelons. By the time of the first five-year plan in 1928, Trotsky was no longer a leader.

The Politburo ousted him from the Kremlin, and he and his family lost 
their living quarters and other party privileges. His private papers demonstrate his desire for Soviet Russia's industrial competitiveness in a world economy and administrative efficiency. Like Stalin, Trotsky supported state economic planning, but through the use of less violent and more democratic methods. Plagued by periodic bouts of illness, Trotsky remained a revolutionary writer rather than a politician.

He was expelled from the USSR and sent to Turkey in 1929 for forming an anti-Soviet party and inciting counter-revolution. There he observed dramatic transformations in the Russian and international economies. The USSR had doubled its industrial output by 1932 and the stock market crash heightened his hopes for a socialist order. Stalin viewed Trotsky's political aim to restore Leninism as a conspiracy and wanted him dead. He and his family lived as runaways abroad and eventually settled in Mexico, ensconced in a villa that acted as a fortress. There his devotion to his wife Natalya survived an extra-marital liaison with Frida Kahlo, which caused considerable tensions between him and Diego Rivera. Alarms and Mexican police protection did not deter Roman Mercador from infiltrating Avenida Vienna and assassinating him in 1940.

Service has written a factual biography, but his goal for a dispassionate analysis mitigates his incisive political and personal interpretation. His concluding statements argue that Trotsky's contradictory ideas endured and that he was a complex human being. Surely such a complicated figure merits more profound observations.

\section{Kathleen Lord}

Mount Allison University

\section{Sharon A. Kowalsky, Deviant Women: Female Crime and Criminology in Revolutionary Russia, 1880-1920 (DeKalb: Northern Illinois University Press, 2009).}

Deviant Women is one of a growing number of studies to situate intellectual and cultural developments in Russia within a larger European context. Kowalsky's discussion of the impact of Cesare Lombroso's theories of criminal types, among other things, demonstrates how Russian criminology was in direct dialogue with the rest of the field in Europe. She also charts the rise of other schools of thought less interested in identifying inborn criminal traits than in emphasizing the role of socioeconomic conditions in causing crime. With the establishment of the Soviet state, criminology became a state-supported scientific discipline, although one that never became dominated by a single approach. The 1920s saw increasing state concern over crime rates, driven by the assumption that crime was supposed to disappear the closer the country came to achieving socialism. Hence, crime statistics were used to chart the country's progress 